\title{
Occupancy of the American Three-Toed Woodpecker in a Heavily-Managed Boreal Forest of Eastern Canada
}

\author{
Vincent Lamarre ${ }^{1}$ (D) and Junior A. Tremblay ${ }^{1,2, *(D)}$ \\ 1 Science and Technology Branch, Environment and Climate Change Canada, 1550 Avenue d'Estimauville, \\ Québec, QC G1J 0C3, Canada; vincent.lamarre@canada.ca \\ 2 Département des Sciences du Bois et de la Forêt, Université Laval, 2405 rue de la Terrasse, \\ Québec, QC G1V 0A6, Canada \\ * Correspondence: junior.tremblay@canada.ca
}

\section{check for}

updates

Citation: Lamarre, V.; Tremblay, J.A. Occupancy of the American

Three-Toed Woodpecker in a

Heavily-Managed Boreal Forest of

Eastern Canada. Diversity 2021, 13,

35. https://doi.org/10.3390/

d13010035

Received: 17 December 2020

Accepted: 15 January 2021

Published: 19 January 2021

Publisher's Note: MDPI stays neutral with regard to jurisdictional claims in published maps and institutional affiliations.

Copyright: (c) 2021 by the authors. Licensee MDPI, Basel, Switzerland. This article is an open access article distributed under the terms and conditions of the Creative Commons Attribution (CC BY) license (https:// creativecommons.org/licenses/by/ $4.0 /)$.

\begin{abstract}
The southern extent of the boreal forest in North America has experienced intensive human disturbance in recent decades. Among these, forest harvesting leads to the substantial loss of late-successional stands that include key habitat attributes for several avian species. The American Three-toed Woodpecker, Picoides dorsalis, is associated with continuous old spruce forests in the eastern part of its range. In this study, we assessed the influence of habitat characteristics at different scales on the occupancy of American Three-toed Woodpecker in a heavily-managed boreal landscape of northeastern Canada, and we inferred species occupancy at the regional scale. We conducted 185 playback stations over two breeding seasons and modelled the occupancy of the species while taking into account the probability of detection. American Three-toed Woodpecker occupancy was lower in stands with large areas recently clear-cut, and higher in landscapes with large extents of old-growth forest dominated by black spruce. At the regional scale, areas with high probability of occupancy were scarce and mostly within protected areas. Habitat requirements of the American Three-toed Woodpecker during the breeding season, coupled with overall low occupancy rate in our study area, challenge its long-term sustainability in such heavily managed landscapes. Additionally, the scarcity of areas of high probability of occupancy in the region suggests that the ecological role of old forest outside protected areas could be compromised.
\end{abstract}

Keywords: boreal forest; clear-cutting; conservation; forest management; old-growth forest; Picoides dorsalis; protected areas

\section{Introduction}

The boreal forest represents about $48 \%$ of the world's forested biomes [1]. Boreal landscapes are shaped by natural disturbances such as windthrows, forest fires and insect outbreaks that generate a complex mosaic in vegetation structure and composition [2,3]. For several decades, however, the exploitation of natural resources has been adding to natural disturbances in this biome [4] and has modified the structure and composition of boreal ecosystems, including the reduction of late-successional stands called old-growth forests $[5,6]$.

Old-growth boreal forests are characterized, among several attributes, by irregular vertical and horizontal structures, large volumes of deadwood either standing (snags) or fallen (coarse woody debris) and in different decaying stages [7]. These attributes are considered key for hundreds of species that depend upon dead or decaying woody material during some part of their life cycle and that are found disproportionately in old-growth forests [8,9]. The temporal continuity of these ecological attributes is also an essential characteristic for many species $[10,11]$. For instance, a recent study highlights the continuous supply of large slightly decayed snags in specific old-growth forest type as a key element to provide temporal stability in the foraging habitat of the Black-backed Woodpecker, Picoides arcticus [12]. 
Deadwood provides foraging or breeding substrate for several vertebrate species [13]. Boreal woodpeckers, for example, are "ecosystem engineers" that create nesting cavities for other vertebrates and are considered indicator species for deadwood-associated biodiversity $[14,15]$. Among woodpecker species found within the boreal biome in North America, the American Three-toed Woodpecker, Picoides dorsalis, is the most strongly associated with continuous old spruce forests at the landscape scale [16-18]. Harvesting, especially of oldgrowth coniferous forests, is thought to be detrimental to the species by limiting the supply of deadwood [16,18-20]. However, most of the studies on the species in eastern Canada occurred in regions where forests were harvested for the first time and where mature and old stands were still relatively abundant amongst residual forests. In heavily-managed forest landscapes, the persistence of the species remains uncertain. Indeed, in a recent attempt to gain insight on the breeding ecology of American Three-toed Woodpecker in heavily managed forest at the southern edge of its breeding range (New-Brunswick, Canada), Craig et al. [21] reported the species in only $5.9 \%$ of the playback stations, and found no predictors of site occupancy although most nests were found in recently dead black spruce trees.

Here, we assess the influence of habitat characteristics at the stand and landscape scales on the occupancy of American Three-toed Woodpecker during the breeding period in a heavily-managed, unburned boreal forest landscape of eastern Canada, and infer the probability of occupancy of the species at the regional scale. We expect that American Three-toed Woodpecker occupancy would be favoured by old spruce forest stands but negatively affected by recently harvested forest stands and higher forest fragmentation, and that the probability of occupancy of the species at the regional scale would be low.

\section{Materials and Methods}

\subsection{Study Area}

This study was conducted at the Forêt Montmorency (Université Laval's Experimental Forest), and the Réserve Faunique des Laurentides, Québec, Canada $\left(47^{\circ} 4^{\prime} \mathrm{N} .71^{\circ} 0^{\prime} \mathrm{W}\right.$.; Figure 1). The study area covers approximately $210 \mathrm{~km}^{2}$ within the balsam fir-white birch bioclimatic domain in the continuous boreal forest subzone [22], which represents the southernmost section of the boreal forest in eastern Canada [23]. More precisely, the study area is classified within the high-elevation balsam fir-white birch zone with elevation ranging between 600 and $1100 \mathrm{~m}$ [24]. Forest stands within the study area are dominated by balsam fir Abies balsamea and black spruce Picea mariana, the latter being more abundant at higher elevation. Companion species are white birch (Betula papyrifera), white spruce (Picea glauca), and tamarack (Larix laricina). In the region, average age-class structure of the natural variability observed over the last few centuries includes $86 \%$ of old forest stands [25]. However, intensive logging during the 20th and early 21st century led to a net reduction in the cover of mature and old forest stands [26]. During the 1909-2005 time frame, $105 \%$ of the high-elevation boreal landscape has been harvested with some areas logged twice [27]. Consequently, the studied area is now dominated by young regenerating stands (0-19 years; $39 \%)$, while the cover of old forests ( $>90$ years) is approximately $25 \%$. Young closed (20-59 years) and mature (60-89 years) forests as well as non-forested lands (e.g., lakes, wetlands, etc.) respectively cover 11, 16 and $9 \%$ of the study area. Dominant cover tree species of old forest stands are balsam fir $(55 \%)$, black spruce $(42 \%)$ and tamarack (3\%). 


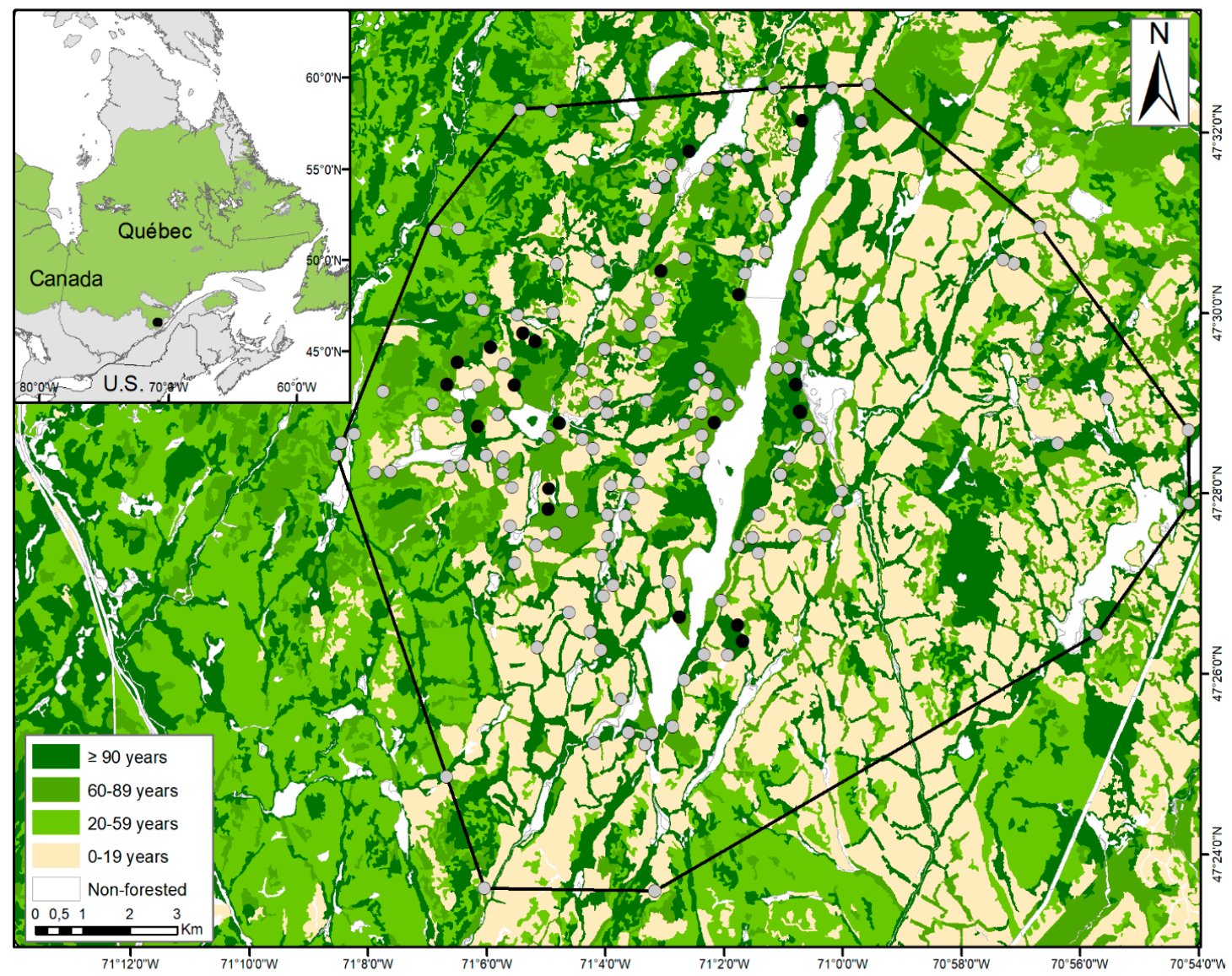

Figure 1. Habitat composition and location of surveyed stations where American Three-toedWoodpecker was detected (black circles) and not detected (grey circles) during occupancy surveys conducted between 2016 and 2017 within the Forêt Montmorency and the Réserve Faunique des Laurentides (Québec, Canada). Boundaries of the boreal zone [28] are delimited by the green zone in the left insert. The black line delineates the boundaries of the study area in the large insert.

\subsection{Woodpecker Surveys}

In 2016 and 2017, we conducted woodpecker occupancy surveys during American Three-toed Woodpecker breeding season at stationary stations distributed along forest roads. We did not stratify the sampling per se but rather targeted areas with clusters of unharvested patches within the vicinity of old forest stands. Surveyed stations were distanced by a minimum of $255 \mathrm{~m}$ (mean \pm standard deviation: $554 \pm 442 \mathrm{~m}$; range 255-3414 m), while mean elevation at stations was $889 \pm 37 \mathrm{~m}$ (range 819-1015 m). Surveys lasted five minutes (300 s), during which conspecific playbacks were displayed, and we noted the time elapsed since the start of the playback when an individual was observed or heard. Similar to the method used by Craig et al. [21], the 300-s conspecific display was divided into two 120-s observation periods which constituted the two visits used in occupancy analyses (see below). Both observation periods were interspersed by a 60-s pause. Playbacks were mixed from recordings obtained from xeno-canto [29] and the Macaulay Library [30]. Playbacks could be heard to approximately $450 \mathrm{~m}$ by the human ear in the field. We conducted surveys between 5:47 a.m. and 3:32 p.m., when precipitations were absent or minimal and wind speed $\leq 3$ on the Beaufort scale $\left(12-19 \mathrm{~km} \mathrm{~h}^{-1}\right)$. Afterward, we accessed three-hour mean wind speed from the nearest weather station located $18 \mathrm{~km}$ northwest of the study area for further analysis [31]. 


\subsection{Habitat Characteristics}

We investigated the influence of habitat characteristics that were likely to affect the occupancy of American Three-toed Woodpecker by calculating vegetation covariates within buffers of 250 and $750 \mathrm{~m}$-radii centered on each surveyed station, representing respectively the stand and landscape scales. The landscape scale was selected based on home range size estimates obtained for one female and two male American Three-toed Woodpeckers during the nesting period in the study area, which averaged 177 ha (J.A. Tremblay, unpublished data). Vegetation covariates were calculated using the eco-forestry layers available as of 2017 for the study area [32]. At the stand scale, we calculated the area (ha) covered by recent clear-cut stands clear_cut. At the stand and landscape scales, we measured the area (ha) covered by old forest ( $\geq 90$ years) dominated by black spruce old_spruce and mean forest age mean_age. We weighted mean_age by the area covered by even-aged stands within the buffers around each surveyed station. We calculated the standard deviation of mean stand age sd_age as an index of habitat fragmentation at the landscape scale. Based on the literature in eastern Canada [16-18], the area covered by non-forested lands in the landscape, the area covered by young ( $20-59$ years) and mature (60-89 years) forests at the stand and landscape scales have been considered marginal for the American Threetoed Woodpecker in the selection of its habitat during the breeding season and thus were excluded from occupancy analyses (see below). We nevertheless compared mean value of all habitat characteristics between stations where the American Three-toed Woodpecker was detected, not detected and a set of 185 random stations distributed randomly into the study (Table 1) area using a Kruskal-Wallis test in $R$ statistical environment version 4.0.2 [33].

Table 1. Description and mean values \pm standard deviation (s.d.) of habitat characteristics measured at the stand (250 m-radii) and landscape (750 m-radii) scales at stations where the American Three-toed Woodpecker was detected, not detected and at random stations during occupancy surveys in managed boreal forest in eastern Canada. Shared letters indicate no significant differences in habitat characteristics among stations (Kruskal-Wallis test). Habitat characteristics in bold are included in occupancy analyses.

\begin{tabular}{|c|c|c|c|c|}
\hline $\begin{array}{c}\text { Habitat } \\
\text { Characteristic }\end{array}$ & Description & $\begin{array}{l}\text { Not Detected } \\
\quad(n=163)\end{array}$ & $\begin{array}{l}\text { Detected } \\
(\mathrm{n}=22)\end{array}$ & $\begin{array}{l}\text { Random } \\
(\mathrm{n}=185)\end{array}$ \\
\hline clear_cut_250 & Area (ha) covered by recent ( $0-19$ years) clear-cut & $6.58(4.62)^{\mathrm{a}}$ & $3.91(4.17)^{b}$ & $6.60(5.89)^{\mathrm{a}}$ \\
\hline mean_age_250 & \multirow{2}{*}{ Mean forest age (year) } & $70.78(25.44)^{\mathrm{a}}$ & $83.27(30.27)^{\mathrm{a}}$ & $64.92(32.34)^{b}$ \\
\hline mean_age_750 & & $70.07(15.34)^{\mathrm{a}}$ & $76.27(20.63)^{\text {a }}$ & $64.33(19.47)^{b}$ \\
\hline young_250 & \multirow{2}{*}{ Area (ha) covered by young closed forest ( $20-59$ years) } & $1.29(2.96)^{\mathrm{a}}$ & $0.86(1.54)^{a, b}$ & $3.24(5.06)^{b}$ \\
\hline young_750 & & $14.71(24.20)^{\mathrm{a}}$ & $8.34(10.62)^{a}$ & $27.03(35.24)^{b}$ \\
\hline mature_250 & \multirow{2}{*}{ Area (ha) covered by mature forest (60-89 years) } & $4.87(4.64)^{a} \mathrm{a}$ & $6.23(5.72)^{a}$ & $3.11(3.80)^{b}$ \\
\hline mature_750 & & $38.49(21.80)^{\mathrm{a}}$ & $48.89(23.05)^{\mathrm{a}}$ & $28.00(22.32)^{b}$ \\
\hline old_spruce_250 & \multirow{2}{*}{$\begin{array}{c}\text { Area (ha) covered by old forest ( } \geq 90 \text { years) dominated by black } \\
\text { spruce }\end{array}$} & $2.92(3.04)^{a}$ & $3.85(3.46)^{a}$ & $2.26(3.51)^{b}$ \\
\hline old_spruce_750 & & $21.87(13.18)^{a}$ & $26.00(16.33)^{\mathrm{a}}$ & $19.92(15.08)^{\mathrm{a}}$ \\
\hline sd_age_750 & Standard deviation of forest age & $56.71(8.89)^{a}$ & $53.08(9.35)^{\mathrm{a}}$ & $54.62(9.80)^{\mathrm{a}}$ \\
\hline nf_750 & Area (ha) covered by non-forested lands in the landscape & $21.04(19.98)^{a}$ & $26.44(23.93)^{a}$ & $12.00(16.16)^{b}$ \\
\hline
\end{tabular}

\subsection{Occupancy Analyses}

We used single-species occupancy modeling in the unmarked R library to investigate the influence of habitat characteristics on the probability of occupancy of American Three-toed Woodpecker $[34,35]$. We converted survey detections of American Three-toed Woodpecker into presence-absence data. To account for imperfect detection probability during surveys, we first estimated the effect of year, Julian day, wind speed $\left(\mathrm{m} \mathrm{s}^{-1}\right)$ and hour of the day on detection probability of American Three-toed Woodpecker. We used a two-step approach [36] to determine which detection parameter(s) to retain in the occupancy models. We first estimated the effect of each detection parameter by ranking univariate models in which occupancy was held constant. We also included a null model in which detection and occupancy were held constant (Table A1). The five candidate models were ranked based 
on the second-order Akaike's information criterion AICc [37]; using the aictab function of the AICcmodavg R library [38].

We developed a set of 10 biologically relevant candidate occupancy models representing hypotheses to investigate the influence of habitat characteristics on the probability of occupancy of American Three-toed Woodpecker (Table 2). This set also included a null model of constant occupancy. Strongly correlated covariates ( $|r| \geq 0.60$; Table A2) were not included in the same candidate model to reduce multicollinearity. We ranked candidate models based on the $\mathrm{AIC}_{\mathrm{c}}$ and we made inference on the top models with $\triangle \mathrm{AICc}<2$. Parameter-averaged predictions of covariates appearing in the most parsimonious models were calculated over their measured range while holding other variables at their mean value. Finally, we inferred a predicted probability of occupancy of American Three-toed Woodpecker from the top models (Table 2) at the regional scale (30 $\mathrm{km} \times 30 \mathrm{~km}$ square zone) within the balsam fir-white birch bioclimatic domain.

Table 2. Candidates models, number of parameters $(k)$, second-order Akaike's information criterion (AICc), $\triangle \mathrm{AICc}, \mathrm{Akaike}$ weights $(\omega)$, log-likelihood (LL) of the candidate models assessing occupancy $(\psi)$ and detection probability $(p)$ of American Three-toed Woodpecker in a managed boreal forest in eastern Canada.

\begin{tabular}{|c|c|c|c|c|c|}
\hline Candidate Model & $k$ & $\mathrm{AIC}_{\mathrm{c}}$ & $\Delta \mathrm{AIC}_{\mathrm{c}}$ & $\omega$ & LL \\
\hline$\sim p$ (time) $\sim \psi($ clear_cut_250 + old_spruce_750 $)$ & 5 & 176.56 & 0.00 & 0.49 & -83.11 \\
\hline$\sim p$ (time) $\sim \psi($ clear_cut_250) & 4 & 178.46 & 1.90 & 0.19 & -85.12 \\
\hline$\sim p($ time $) \sim \psi($ mean_age_250 + sd_age_750) & 5 & 178.99 & 2.43 & 0.15 & -84.33 \\
\hline$\sim p($ time $) \sim \psi($ clear_cut_250 + mean_age_750) & 5 & 180.22 & 3.65 & 0.08 & -84.94 \\
\hline$\sim p($ time $) \sim \psi($ mean_age_250) & 4 & 182.46 & 5.89 & 0.03 & -87.12 \\
\hline$\sim p($ time $) \sim \psi($ old_spruce_250 + sd_age_750) & 5 & 182.76 & 6.20 & 0.02 & -86.21 \\
\hline$\sim p($ time $) \sim \psi($ sd_age_750) & 4 & 183.63 & 7.06 & 0.01 & -87.70 \\
\hline $\begin{array}{l}\sim p(\text { time }) \sim \psi(\text { mean_age_250 + } \\
\text { old_spruce_750) }\end{array}$ & 5 & 183.86 & 7.30 & 0.01 & -86.76 \\
\hline$\sim p$ (time) $\sim \psi($ null $)$ & 3 & 185.05 & 8.49 & 0.01 & -89.46 \\
\hline$\sim p$ (time) $\sim \psi($ old_spruce_250) & 4 & 185.25 & 8.68 & 0.01 & -88.51 \\
\hline
\end{tabular}

\section{Results}

Between 19 May and 13 July 2016 and between 26 May and 29 June 2017, we broadcasted American Three-toed Woodpecker playbacks at 185 stations, including 35 revisited stations in 2017. American Three-toed Woodpecker was detected at $22(11.9 \%)$ of the 185 stations. Forest composition and structure differed between sampled and random stations since we targeted our sampling effort towards clusters of older residual forest patches distributed close to non-forested lands such as waterbodies and wetlands in the study area (Table 1). Indeed, mean forest age at the stand and landscape scale and the area covered by old spruce at the stand scale were lower at random than sampled stations. In addition, the area covered by mature stands at both scales was also lower at random stations, while the dominance of young stands tended to be greater. Finally, non-forested habitats in the landscape were less important at random than sampled stations (Table 1).

Time of the day was retained in the most parsimonious model and accounted for $42 \%$ of model selection weight (Table A1). The models including year $\left(\triangle \mathrm{AIC}_{\mathrm{C}}=1.61\right)$ and date $\left(\triangle \mathrm{AIC}_{\mathrm{C}}=1.95\right)$ were equivalent and did not differ from the null model $\left(\Delta \mathrm{AIC} \mathrm{C}_{\mathrm{C}}=1.77\right)$. Only time of the day influenced the probability of detection of American Three-toed Woodpecker ( $p_{\text {time }}: 0.37,95 \%$ C.I.: $\left.[0.03,0.71]\right)$ and therefore was the only detection parameter included in occupancy models. Mean occupancy rate of American Three-toed Woodpecker in the study site was $0.17 \pm 0.04$, and mean detection probability when the time of the day was fixed to its mean value was $0.48 \pm 0.11$. 
Two models had a substantial level of empirical support in influencing occupancy of the American Three-toed Woodpecker $\left(\Delta \mathrm{AIC}_{\mathrm{C}}<2\right.$; Table 2$)$. Together, these models accounted for $68 \%$ of the AIC weight. At the stand scale, occupancy of American Three-toed Woodpecker decreased with increasing recent clear-cut area $\left(\psi_{\text {clear_cut_250 }}:-0.20,95 \%\right.$ C.I.: [-0.34, -0.06$]$, Figure 2a). The area covered by recent clear-cuts at the stand scale was also lower at stations where American Three-toed Woodpecker was detected compared to stations where the species was not detected or random stations (Table 1). At the landscape scale, occupancy of the species tended to increase with an increase in the area covered by old forest dominated by black spruce ( $\psi_{\text {old_spruce_750 }}$ : 0.04, 95\% C.I.: [0.00-0.08], Figure $2 \mathrm{~b}$ ), with increasing uncertainty in confidence intervals $>40$ ha most likely due to the scarcity of large old spruce forest stands in our study area.

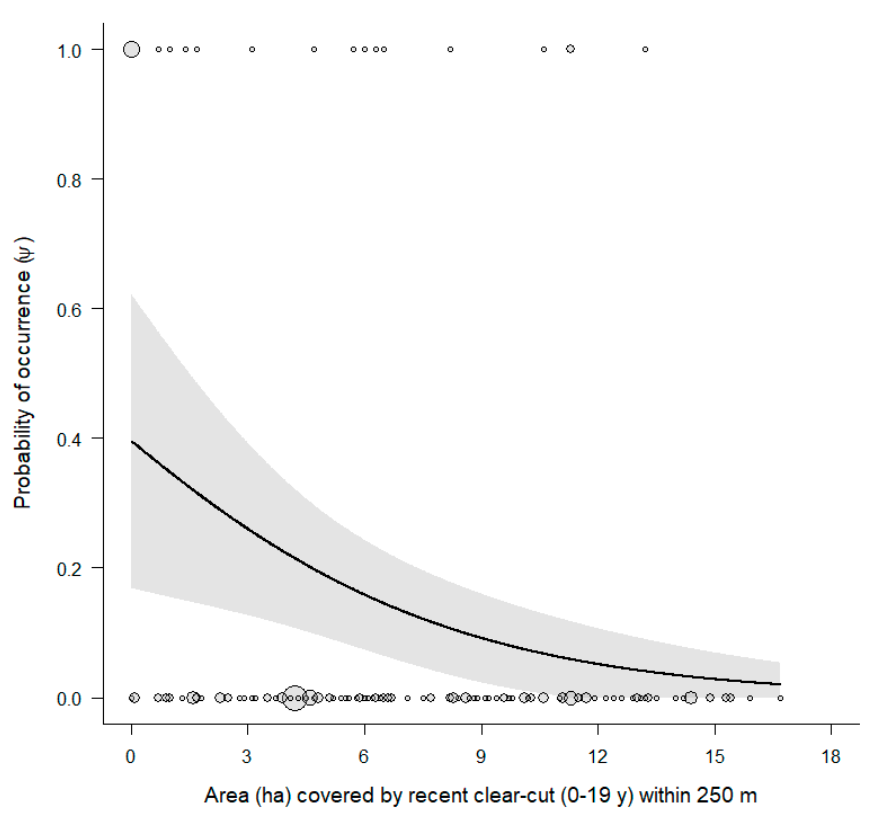

(a)

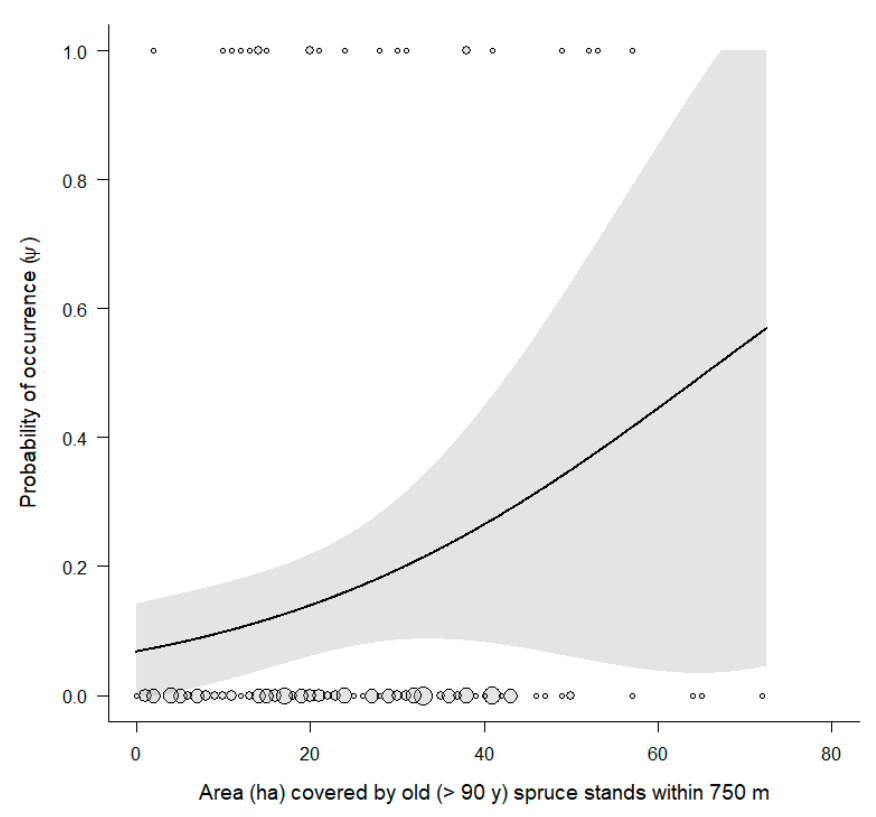

(b)

Figure 2. Influence on the occupancy of American Three-toed Woodpecker in managed boreal forest in eastern Canada of the area (ha) covered by (a) recent clear-cut stands at the stand scale (250 m radii) and (b) old spruce stands at the landscape scale (750 m radii). The shaded grey area represents $95 \%$ confidence interval, and symbols represent the distribution of raw data with symbol size proportional to the $(\log +1)$ number of observations.

Extrapolating results inferred from our top occupancy models (Table 2) to a larger extent within the balsam fir-white birch bioclimatic domain showed that only $12.3 \%$ of the region had moderate- to high-predicted probability of occupancy $(>0.5)$ of the American Three-toed Woodpecker. About half of these areas (6.7\%) were located within protected areas. Areas with high-predicted probability of occupancy $(>0.75)$ of the species represented $4.7 \%$ of the region where only $1.0 \%$ were in managed forests outside protected areas (Figure 3). 


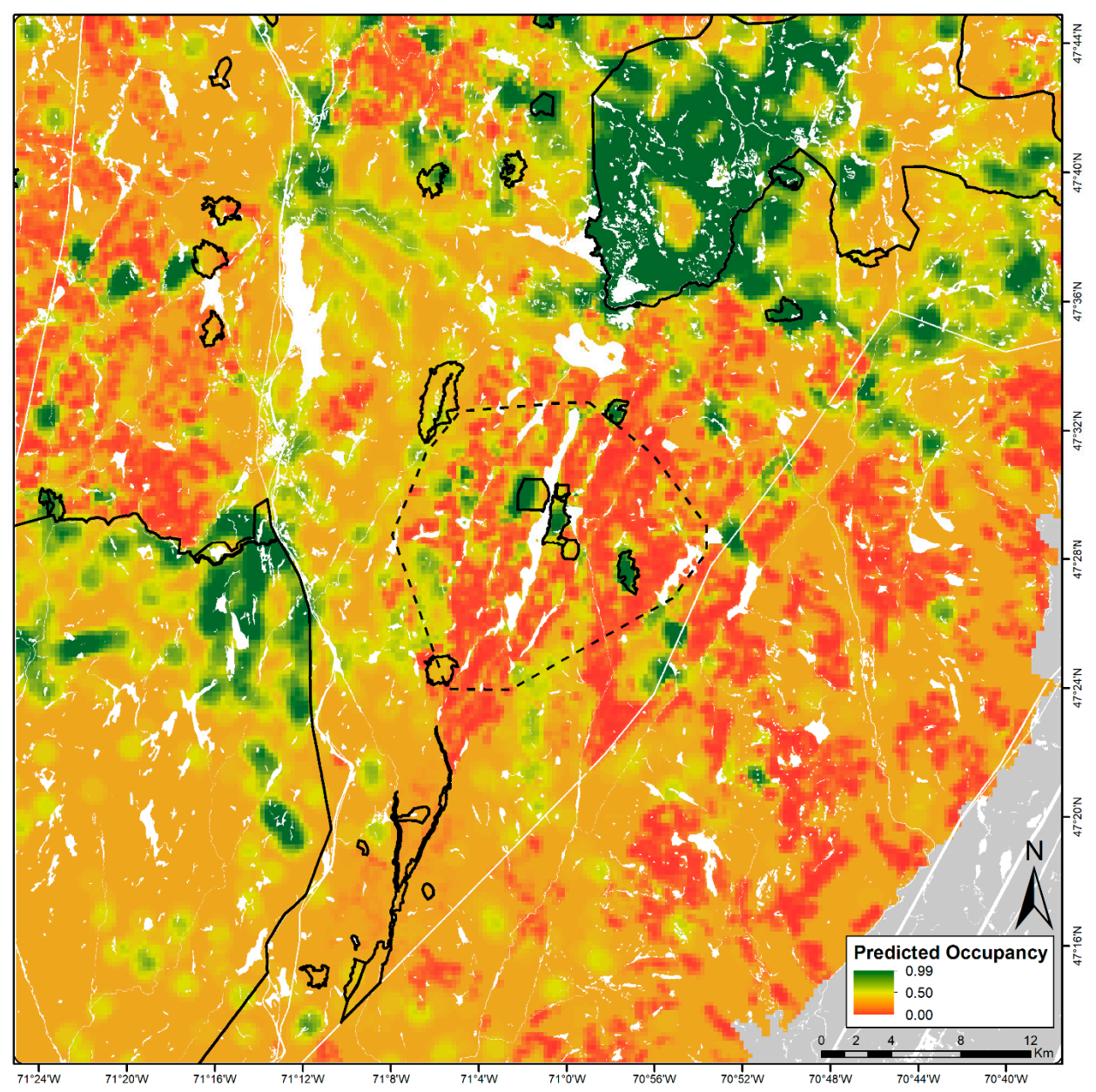

Figure 3. Predicted probability of occupancy of American Three-toed Woodpecker at the regional scale within the balsam fir-white birch bioclimatic domain. Probability of occupancy is inferred from the top-ranking models $\left(\triangle \mathrm{AIC}_{\mathrm{c}}<2\right.$; Table 2$)$. The dashed and solid black lines respectively delineate the boundaries of the study area and protected areas and white polygons indicate non-forested lands.

\section{Discussion}

In a heavily-managed landscape at the southern edge of the boreal forest, the American Three-toed Woodpecker exhibited a low mean occupancy rate $(0.17 \pm 0.04)$ where its probability of occupancy decreased rapidly with increasing area of recent clear-cut at the stand scale. The amount of old spruce forest was positively associated with species occupancy at the landscape scale. Our results suggest that logging history in the region may have created an unsuitable forest landscape (i.e., dominated by younger age-classes and fragmented residual older forest stands) to support a long-term population of American Three-toed Woodpecker.

Habitat associations of the American Three-toed Woodpecker vary across its range. In a meta-analysis focusing on successional trajectories of bird communities following fire and harvesting in boreal forests of western Canada, Schiek and Song [39] report the American Three-toed Woodpecker more common in older mixed wood and white spruce. In western Quebec, Imbeau and Desrochers [16] document a positive association between the American Three-toed Woodpecker with the amount of old spruce forest in continuous coniferous forest. Similarly, Cadieux and Drapeau [18] report a higher occurrence of the species in black spruce forest stands older than 90 years and no occurrence in younger coniferous stands. Accordingly, we find that the occupancy of the American Three-toed Woodpecker during the breeding period increases with old spruce forest stands in a managed landscape. This result agrees with our prediction as it has been shown that the 
American Three-toed Woodpecker preferentially forages on relatively large and senescent or recently dead coniferous trees to access bark-associated beetles (Scolytinae) by scaling layers of bark with strong preference for black spruce in eastern Canada [17,40,41].

Recent clear-cut at the stand scale have a negative effect on the occupancy of the American Three-toed Woodpecker. This result agrees with our expectation and with previous studies about the sensitivity of the species to forest harvesting, especially in the eastern part of its distribution range [19,20,41,42]. Accordingly, in the black spruce moss domain of eastern Canada, recent clear-cuts have a lower density of snags, and the American Three-toed Woodpecker is solely found in old-growth forest [19]. In addition to a reduction in the deadwood abundance, long-term recruitment of large-diameter snags is compromised in clear-cut stands [43]. In a closely-related species, the Black-backed Woodpecker, old coniferous forests with a greater volume of recently dead trees than adjacent recent cuts are selected for foraging during the breeding period [44]. Similar foraging avoidance of recent clear-cut areas may be occurring in our study site for the American Three-toed Woodpecker. Indeed, timber harvesting peaked during the period 1996-2004 and ended in 2009, and although we did not quantify the volume and decay stages of deadwood, it is reasonable to think that most deadwood in clear-cuts had entered late decay classes and was of low quality for foraging American Three-toedWoodpecker at the time of our study.

Our results do not report a predictive effect of habitat fragmentation at the landscape scale on the occupancy of the American Three-toed Woodpecker. Forest edge avoidance by foraging American Three-toed Woodpecker has been reported, where high-quality substrates near stand edges are used less frequently than available [41]. In addition, movements of foraging woodpeckers also appear to be constrained in residual forests following harvesting $[16,41]$. Hence, the effect of habitat fragmentation seems to act on a finer scale, and our results suggest that at a larger scale (i.e., landscape), the amount of old forests may strongly influence the occurrence of the species. For instance, most of our detection of the species occurred close to forest patches of mature or old forests rather than residual strips of forest (Figure 1).

Only $1 \%$ of the forest stands in managed forests at the regional scale show high predicted probability of occupancy of the American Three-toed Woodpecker. This is likely a consequence of forestry practices, mainly driven by clear-cutting during the last century which has led to a substantial reduction of old forest cover in the region [26,27]. Such practices can hardly sustain biodiversity associated with old coniferous forest stands, especially for species with large home ranges. For example, habitat alteration from anthropogenic activities is a threat of high concern for populations of Woodland Caribou Rangifer tarandus caribou across Canada's boreal biomes, including the local population in our study area, which is considered "not self-sustaining" [45]. Fennoscandia previously experienced a similar situation where old-growth forests have almost completely disappeared [46,47], and it is estimated that $30-50 \%$ of the red-listed species in these regions are associated with old-growth forest attributes $[48,49]$. In boreal ecosystems, conservation strategies cannot be based solely on a network of protected areas but rather on how unprotected areas are managed [50]. Hence, management practices mimicking the attributes of old-growth forests by ensuring a continuous recruitment of deadwood appear important for maintaining species associated with old spruce forests. Within these practices, partial harvesting may be efficient in maintaining a relatively high abundance of deadwood and associated deadwood-dependent species such as the American Three-toed Woodpecker [51,52], although the efficiency of such practices has not yet been assessed. The ecological role of old forests in our study area seems to be altered, and the situation may require revised management practices and a passive restoration of the ecological integrity of old forests outside protected areas in the region sensu [53]. 


\section{Conclusions}

With 185 stations sampled over two breeding seasons, our study on the occupancy of the American Three-toed Woodpecker is one of the first conducted in a heavily harvested landscape at the southern edge of the boreal forest. The overall low occupancy of the species within our study area raises questions about the long-term sustainability of such heavily managed landscapes for the American Three-toed Woodpecker. Areas of highpredicted occupancy of the species in the studied region are mostly found in protected areas, providing evidence that heavy forest harvesting is a detrimental driver that likely contributed to the significant long-term declining trends of the species over the 1970-2019 period in the province of Québec $\left(-0.96 \%\right.$.year ${ }^{-1}$; 95\% C.I.: [ $\left.-0.70--1.22\right]$; [54]) and at a larger scale in the boreal hardwood transition bird conservation region $\left(-3.5 \%\right.$.year ${ }^{-1}$; 95\% C.I.: [-2.0--5.2]; [55]). The southern part of the boreal forest in eastern Canada, where we conducted our study, has experienced one of the most important human disturbances in the past decades, mainly related to forest harvesting [4]. We pledge for more detailed studies on this discrete keystone species in different regions with varying forest harvesting intensity, at the stand scale (going from clear-cutting to partial harvesting) and landscape scale (from pristine to heavily harvested), focusing on demographic parameters (i.e., reproductive success and survival) and habitat selection.

Author Contributions: Conceptualization, J.A.T.; methodology, J.A.T.; formal analysis, J.A.T., V.L.; investigation, J.A.T., V.L.; resources, J.A.T.; data curation, V.L.; writing —original draft preparation, V.L.; writing - review and editing, J.A.T., V.L.; visualization, V.L.; supervision, J.A.T.; project administration, J.A.T.; funding acquisition, J.A.T. All authors have read and agreed to the published version of the manuscript.

Funding: This research was funded by Environment and Climate Change Canada.

Institutional Review Board Statement: Not applicable.

Informed Consent Statement: Not applicable.

Data Availability Statement: The data presented in this study are openly available in https:// doi. org/10.5061/dryad.9kd51c5gc.

Acknowledgments: We are grateful to André Desrochers for sharing the code to calculate habitat characteristics and to Mark J. Mazerolle for advice related to statistical analyses. We are also thankful to the personnel at the Forêt Montmorency for their support and to Michel Robert for the loan of allterrain vehicles. Finally, we thank Francis Lessard and Julien St-Amand for their help with fieldwork.

Conflicts of Interest: The authors declare no conflict of interest. The funders had no role in the design of the study; in the collection, analyses, or interpretation of data; in the writing of the manuscript, or in the decision to publish the results.

\section{Appendix A}

Table A1. Model selection based on the $\mathrm{AIC}_{\mathrm{c}}$ for the estimation of detection probability ( $p$ ) of American Three-toed Woodpecker in managed boreal forest in eastern Canada. The number of parameters $(k)$, second-order Akaike's information criterion $\left(\mathrm{AIC}_{\mathrm{c}}\right), \triangle \mathrm{AIC}_{\mathrm{C}}$, Akaike weights $(\omega)$, log-likelihood $(\mathrm{LL})$ are included in the table and occupancy $(\psi)$ is held constant for each candidate model.

\begin{tabular}{cccccc}
\hline $\begin{array}{c}\text { Candidate } \\
\text { Model }\end{array}$ & $\boldsymbol{k}$ & $\mathbf{A I C}_{\mathbf{c}}$ & $\boldsymbol{\Delta} \mathbf{A I C}_{\mathbf{c}}$ & $\boldsymbol{\omega}$ & $\mathbf{L L}$ \\
\hline$\sim p$ (time) & 3 & 185.05 & 0.00 & 0.42 & -89.46 \\
$\sim p$ (year) & 3 & 186.66 & 1.61 & 0.19 & -90.27 \\
$\sim p$ (null) & 2 & 186.82 & 1.77 & 0.17 & -91.38 \\
$\sim p$ (date) & 3 & 187.00 & 1.95 & 0.16 & -90.44 \\
$\sim p$ (wind) & 3 & 188.60 & 3.55 & 0.07 & -91.23 \\
\hline
\end{tabular}


Table A2. Correlation among habitat characteristics included in occupancy analyses.

\begin{tabular}{|c|c|c|c|c|c|c|}
\hline & mean_age_250 & clear_cut_250 & old_spruce_250 & mean_age_750 & sd_age_750 & old_spruce_750 \\
\hline mean_age_250 & 1 & & & & & \\
\hline clear_cut_250 & -0.53 & 1 & & & & \\
\hline old_spruce_250 & 0.42 & 0.03 & 1 & & & \\
\hline mean_age_750 & 0.66 & -0.36 & 0.19 & 1 & & \\
\hline sd_age_750 & 0.19 & 0.31 & 0.32 & 0.28 & 1 & \\
\hline old_spruce_750 & 0.29 & 0.17 & 0.60 & 0.37 & 0.23 & 1 \\
\hline
\end{tabular}

\section{References}

1. Brandt, J.P.; Flannigan, M.D.; Maynard, D.G.; Thompson, I.D.; Volney, W.J.A. An Introduction to Canada's Boreal Zone: Ecosystem Processes, Health, Sustainability, and Environmental Issues. Environ. Rev. 2013, 21, 207-226. [CrossRef]

2. Kneeshaw, D.D.; Bergeron, Y. Canopy Gap Characteristics and Tree Replacement in the Southeastern Boreal Forest. Ecology 1998, 79, 783-794. [CrossRef]

3. Bergeron, Y.; Harvey, B.; Leduc, A.; Gauthier, S. Forest Management Guidelines Based on Natural Disturbance Dynamics: Standand Forest-Level Considerations. For. Chron. 1999, 75, 49-54. [CrossRef]

4. Pasher, J.; Seed, E.; Duffe, J. Development of Boreal Ecosystem Anthropogenic Disturbance Layers for Canada Based on 2008 to 2010 Landsat Imagery. Can. J. Remote Sens. 2013, 39, 42-58. [CrossRef]

5. Frank, D.; Finckh, M.; Wirth, C. Impacts of Land Use on Habitat Functions of Old-Growth Forests and their Biodiversity. In OldGrowth Forests. Ecological Studies (Analysis and Synthesis); Wirth, C., Gleixner, G., Heimann, M., Eds.; Springer: Berlin/Heidelberg, Germany, 2009; Volume 207, pp. 429-450. ISBN 978-3-540-92705-1.

6. Grondin, P.; Gauthier, S.; Poirier, V.; Tardif, P.; Boucher, Y.; Bergeron, Y. Have Some Landscapes in the Eastern Canadian Boreal Forest Moved beyond Their Natural Range of Variability? For. Ecosyst. 2018, 5, 30. [CrossRef]

7. Mosseler, A.; Thompson, I.; Pendrel, B.A. Overview of Old-Growth Forests in Canada from a Science Perspective. Environ. Rev. 2003, 11, S1-S7. [CrossRef]

8. Stokland, J.; Siitonen, J. Species diversity of saproxylic organisms. In Biodiversity in Dead Wood; Stokland, J., Siitonen, J., Jonsson, B., Eds.; Cambridge University Press: Cambridge, UK, 2012; pp. 248-274. ISBN 978-1-139-02584-3.

9. Nilsson, S.G. Selecting biodiversity indicators to set conservation targets: Species, structures, or processes? In Setting Conservation Targets for Managed Forest Landscapes; Villard, M.-A., Jonsson, B.G., Eds.; Cambridge University Press: Cambridge, UK, 2009; pp. 79-108. ISBN 978-0-521-87709-1.

10. Boudreault, C.; Gauthier, S.; Bergeron, Y. Epiphytic Lichens and Bryophytes on Populus Tremuloides Along a Chronosequence in the Southwestern Boreal Forest of Québec, Canada. Bryologist 2000, 103, 725-738. [CrossRef]

11. Bergeron, Y.; Fenton, N.J. Boreal Forests of Eastern Canada Revisited: Old Growth, Nonfire Disturbances, Forest Succession, and Biodiversity. Botany 2012, 90, 509-523. [CrossRef]

12. Martin, M.; Tremblay, J.A.; Ibarzabal, J. An Indicator Species Highlights Continuous Deadwood Supply Is a Key Ecological Attribute of Boreal Old-Growth Forests. Ecosphere. under review.

13. Wesołowski, T.; Martin, K. Tree Holes and Hole-Nesting Birds in European and North American Forests. In Ecology and Conservation of Forest Birds; Mikusiński, G., Roberge, J.-M., Fuller, R., Eds.; Cambridge University Press: Cambridge, UK, 2018; pp. 79-134. ISBN 978-1-139-68036-3.

14. Drapeau, P.; Nappi, A.; Imbeau, L.; Saint-Germain, M. Standing Deadwood for Keystone Bird Species in the Eastern Boreal Forest: Managing for Snag Dynamics. For. Chron. 2009, 85, 227-234. [CrossRef]

15. Tremblay, J.A.; Savard, J.-P.L.; Ibarzabal, J. Structural Retention Requirements for a Key Ecosystem Engineer in Conifer-Dominated Stands of a Boreal Managed Landscape in Eastern Canada. For. Ecol. Manag. 2015, 357, 220-227. [CrossRef]

16. Imbeau, L.; Desrochers, A. Area Sensitivity and Edge Avoidance: The Case of the Three-Toed Woodpecker (Picoides Tridactylus) in a Managed Forest. For. Ecol. Manag. 2002, 249-256. [CrossRef]

17. Nappi, A.; Drapeau, P.; Leduc, A. How Important Is Dead Wood for Woodpeckers Foraging in Eastern North American Boreal Forests? For. Ecol. Manag. 2015, 346, 10-21. [CrossRef]

18. Cadieux, P.; Drapeau, P. Are Old Boreal Forests a Safe Bet for the Conservation of the Avifauna Associated with Decayed Wood in Eastern Canada? For. Ecol. Manag. 2017, 385, 127-139. [CrossRef]

19. Imbeau, L.; Savard, J.-P.L.; Gagnon, R. Comparing Bird Assemblages in Successional Black Spruce Stands Originating from Fire and Logging. Can. J. Zool. 1999, 77, 1850-1860. [CrossRef]

20. Imbeau, L.; Mönkkönen, M.; Desrochers, A. Long-Term Effects of Forestry on Birds of the Eastern Canadian Boreal Forests: A Comparison with Fennoscandia. Conserv. Biol. 2001, 1151-1162. [CrossRef]

21. Craig, C.; Mazerolle, M.J.; Taylor, P.D.; Tremblay, J.A.; Villard, M.-A. Predictors of Habitat Use and Nesting Success for Two Sympatric Species of Boreal Woodpeckers in an Unburned, Managed Forest Landscape. For. Ecol. Manag. 2019, 438, 134-141. [CrossRef]

22. Saucier, J.-P.; Robitaille, A.; Grondin, P.; Bergeron, J.-F.; Gosselin, J. Les Régions Écologiques Du Québec Méridional, 4th ed.; Carte à l'échelle de 1/1 250,000; Ministère Des Ressources Naturelles et de La Faune Du Québec: Quebec, QC, Canada, 2011. 
23. Saucier, J.-P.; Grondin, P.; Robitaille, A.; Gosselin, J.; Morneau, C.; Richard, P.J.H.; Brisson, J.; Sirois, L.; Leduc, A.; Morin, H.; et al. Écologie forestière. In Manuel de Foresterie-Nouvelle Édition Entièrement Revue et Augmentée; Ordre des ingénieurs forestiers du Québec, Ed.; Éditions Mulitmondes: Quebec, QC, Canada, 2009; pp. 165-316.

24. Boucher, Y.; Grondin, P.; Noël, J.; Hotte, D.; Blouin, J.; Roy, G. Classification Des Écosystèmes et Caractérisation Des Forêts Mûres et Surannées: Le Cas Du Projet Pilote de La Réserve Faunique Des Laurentides; Gouvernement du Québec, Ministère des Ressources naturelles et de la Faune, Direction de la Recherche Forestière: Quebec, QC, Canada, 2008.

25. Boucher, Y.; Bouchard, M.; Grondin, P.; Tardif, P. Le Registre Des États de Référence: Intégration Des Connaissances Sur La Structure, La Composition et La Dynamique Des Paysages Forestiers Naturels Du Québec Méridional; Gouvernement du Québec, Ministère des Ressources naturelles et de la Faune, Direction de la recherche forestière: Quebec, QC, Canada, 2011.

26. Desrochers, A.; Drolet, B. Le Programme de Surveillance Des Oiseaux Nicheurs de La Forêt Montmorency: Une Nouvelle Source de Tendances Des Populations d'oiseaux Nicheurs Pour La Forêt Boréale Au Québec. Nat. Can. 2017, 141, 61-74. [CrossRef]

27. Boucher, Y.; Grondin, P. Impact of Logging and Natural Stand-Replacing Disturbances on High-Elevation Boreal Landscape Dynamics (1950-2005) in Eastern Canada. For. Ecol. Manag. 2012, 263, 229-239. [CrossRef]

28. Brandt, J.P. The Extent of the North American Boreal Zone. Environ. Rev. 2009, 17, 101-161. [CrossRef]

29. Xeno-Canto. Available online: https:/ / www.xeno-canto.org/ (accessed on 1 May 2016).

30. Macaulay Library—The Cornell Lab of Ornithology. Available online: https:/ / www.macaulaylibrary.org/ (accessed on 1 May 2016).

31. Weather Archive in Fort Montmorency, METAR. Available online: https://rp5.ru/Weather_archive_in_Fort_Montmorency, _METAR (accessed on 15 August 2020).

32. Ministère des Forêts, de la Faune et des Parcs. Norme de Stratification Écoforestière: Quatrième Inventaire Écoforestier du Québec méridional; Secteur des Forêts. Direction des Inventaires Forestiers: Québec, QC, Canada, 2015; ISBN 978-2-550-73857-2.

33. R Core Team. R: A Language and Environment for Statistical Computing; R Foundation for Statistical Computing: Vienna, Austria, 2020.

34. Mackenzie, D.I.; Nichols, J.D.; Lachman, G.B.; Droege, S.; Royle, J.A.; Catherine, A. Langtimm Estimating Site Occupancy Rates When Detection Probabilities Are Less than One. Ecology 2002, 2248-2255. [CrossRef]

35. Fiske, I.; Chandler, R. Unmarked: An $R$ Package for Fitting Hierarchical Models of Wildlife Occurrence and Abundance. J. Stat. Soft. 2011, 43. [CrossRef]

36. Clement, M.A.; Barrett, K.; Baldwin, R.F. Key Habitat Features Facilitate the Presence of Barred Owls in Developed Landscapes. ACE 2019, 14, art12. [CrossRef]

37. Burnham, K.P.; Anderson, D.R. Model Selection and Multi-Model Inference: A Practical Information-Theoretic Approach, 2nd ed.; Springer: New York, NY, USA, 2002; ISBN 0-387-95364-7.

38. Mazerolle, M.J. AICcmodavg: Model Selection and Multimodel Inference Based on (Q)AIC(c). R Package Version 2.3-0. 2020. Available online: https:/ / repo.bppt.go.id/cran/web/packages/AICcmodavg/vignettes/AICcmodavg.pdf (accessed on 20 May 2020).

39. Schieck, J.; Song, S.J. Changes in Bird Communities throughout Succession Following Fire and Harvest in Boreal Forests of Western North America: Literature Review and Meta-Analyses. Can. J. For. Res. 2006, 36, 1299-1318. [CrossRef]

40. Imbeau, L.; Desrochers, A. Foraging Ecology and Use of Drumming Trees by Three-Toed Woodpeckers. J. Wildl. Manag. 2002, 66, 222. [CrossRef]

41. Gagné, C.; Imbeau, L.; Drapeau, P. Anthropogenic Edges: Their Influence on the American Three-Toed Woodpecker (Picoides dorsalis) Foraging Behaviour in Managed Boreal Forests of Quebec. For. Ecol. Manag. 2007, 252, 191-200. [CrossRef]

42. Hagan, J.M.; McKinley, P.S.; Meehan, A.L.; Grove, S.L. Diversity and Abundance of Landbirds in a Northeastern Industrial Forest. J. Wildl. Manag. 1997, 61, 718. [CrossRef]

43. Vaillancourt, M.-A.; Drapeau, P.; Gauthier, S.; Robert, M. Availability of Standing Trees for Large Cavity-Nesting Birds in the Eastern Boreal Forest of Québec, Canada. For. Ecol. Manag. 2008, 255, 2272-2285. [CrossRef]

44. Tremblay, J.A.; Leonard, D.L., Jr.; Imbeau, L. American Three-toed Woodpecker (Picoides dorsalis). Version 1.0. In Birds of the World; Rodewald, P.G., Ed.; Cornell Lab of Ornithology: Ithaca, NY, USA, 2020.

45. Environment Canada. Recovery Strategy for the Woodland Caribou, Boreal Population (Rangifer Tarandus Caribou) in Canada [Proposed]. Species at Risk Act Recovery Strategy Series; Environment Canada: Ottawa, ON, Canada, 2011; pp. vi + 55.

46. Halme, P.; Allen, K.A.; Auninšs, A.; Bradshaw, R.H.W.; Brūmelis, G.; Čada, V.; Clear, J.L.; Eriksson, A.-M.; Hannon, G.; Hyvärinen, E.; et al. Challenges of Ecological Restoration: Lessons from Forests in Northern Europe. Biol. Conserv. 2013, 167, 248-256. [CrossRef]

47. Shorohova, E.; Kneeshaw, D.; Kuuluvainen, T.; Gauthier, S. Variability and Dynamics of Old-Growth Forests in the Circumboreal Zone: Implications for Conservation, Restoration and Management. Silva Fenn. 2011, 45. [CrossRef]

48. Tikkanen, O.-P.; Martikainen, P.; Hyvärinen, E.; Junninen, K.; Kouki, J. Red-Listed Boreal Forest Species of Finland: Associations with Forest Structure, Tree Species, and Decaying Wood. Ann. Zool. Fennici 2006, 43, 373-383. [CrossRef]

49. Tingstad, L.; Grytnes, J.A.; Felde, V.A.; Juslén, A.; Hyvärinen, E.; Dahlberg, A. The Potential to Use Documentation in National Red Lists to Characterize Red-Listed Forest Species in Fennoscandia and to Guide Conservation. Glob. Ecol. Conserv. 2018, 15, e00410. [CrossRef]

50. Haavik, A.; Dale, S. Are Reserves Enough? Value of Protected Areas for Boreal Forest Birds in Southeastern Norway. Ann. Zool. Fenn. 2012, 49, 69-80. [CrossRef] 
51. Nappi, A. Sélection d’habitat et Démographie Du Pic à Dos Noir Dans Les Forêts Brûlées de La Forêt Boréale. Ph.D. Thesis, Université du Québec à Montréal, Montréal, QC, Canada, 2009.

52. Fenton, N.J.; Imbeau, L.; Work, T.; Jacobs, J.; Bescond, H.; Drapeau, P.; Bergeron, Y. Lessons Learned from 12 Years of Ecological Research on Partial Cuts in Black Spruce Forests of Northwestern Québec. For. Chron. 2013, 89, 350-359. [CrossRef]

53. Tremblay, J.A.; Bélanger, L.; Desponts, M.; Brunet, G. La Restauration Passive Des Sapinières Mixtes de Seconde Venue: Une Alternative Pour La Conservation Des Sapinières Mixtes Anciennes. Can. J. For. Res. 2007, 37, 825-839. [CrossRef]

54. Desrochers, A. Tendances Ornithologiques du Québec. Available online: https:/ /www.toq.ffgg.ulaval.ca/ (accessed on 13 October 2020)

55. Meehan, T.D.; LeBaron, G.S.; Dale, K.; Michel, N.L.; Verutes, G.M.; Langham, G.M. Abundance Trends of Birds Wintering in the USA and Canada, from Audubon Christmas Bird Counts, 1966-2017, Version 2.1; National Audubon Society: New York, NY, USA, 2018. 